\title{
Obituary: Professor Margalith Galun (1927-2012), Founding Editor-in-Chief of Symbiosis
}

\author{
Miriam Balaban
}

Received: 25 May 2012 / Accepted: 25 May 2012 / Published online: 12 June 2012

(C) Springer Science+Business Media B.V. 2012

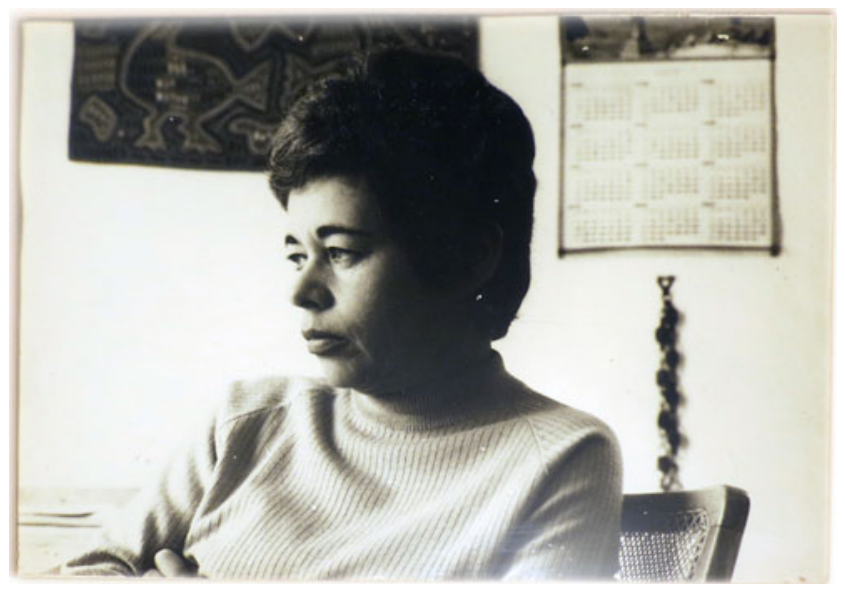

I first met Margalith Galun about half a century ago at the Hebrew University of Jerusalem where she was studying botany with Prof. Thelma Reiss and I was editing the Israel Journal of Botany (and other Israel journals) for the Research Council. We met each other over the years and more frequently after I moved to Rehovot where she and her husband Prof. Esra Galun had moved earlier.

Margalith had studied under Prof. Reichert at the Faculty of Agriculture in Rehovot and then became Professor at Tel

\footnotetext{
M. Balaban ( $\square)$

Rome, Italy

e-mail: desalinationpublications@yahoo.com
}

Aviv University. One day in 1985 Margalith told me about the development of symbiosis into a full important discipline of its own and that it was time to found a journal to gather papers now scattered in disciplines such as botany, microbiololgy, zoology, ecology and many more to find symbiosis articles under one cover to ease communication among symbiosis researchers. As a publisher, I said, let's make one! From that day, it was a fruitful friendly collaboration.

As production editor I offered Suzanne Trauffer who moved to Italy and then to the States. Margalith was concerned about the distance, but since in today's electronic world it is expertise, intelligence and dedication which matter, this turned into a very happy collaboration which continues today with her successor, Prof. David Richardson.

Then Margalith was concerned about distribution of the journal and creating a forum where symbiosis scientists could meet. Thus with the collaboration of friends - Prof. James White, Prof. John Lee, Prof. Sir David Smith and Prof. Douglas Zook - Margalith founded the International Symbiosis Society and organized its first congress in Jerusalem in 1991. Of course Prof. Lynn Margulis was one of the first adherents who earlier had proposed symbiosis as a discipline on its own.

Margalith Galun (née Melitta Katz) was born in Vienna, Austria in 1927. She started elementary school and gymnasium in Vienna and in 1938 left for Switzerland and stayed there with Jewish families for about one year and in 1947 she immigrated with her parents to Israel (then Palestine). She finished elementary school and 
Herzliya High School (in 1946) in Tel Aviv. With friends of a youth organization she went for several months to kibbutz Kfar Giladi. After the death of her mother, Margalith stayed with her father in Tel Aviv and in October 1947 started to study at the Hebrew University of Jerusalem. During the War of Independence she joined the Israeli Army (IDF) and in the middle of 1949 returned to the University to study botany.

In 1953 Margalith married Esra Galun and in 1954 she graduated as M.Sc and also gave birth to her first son Eithan (now an M.D. and professor of medicine). Thereafter Margalith started her PhD studies under the guidance of Professor Israel Reichert and in 1959 delivered her second son, Ehud ( $\mathrm{PhD}$ in chemistry, manager in a major industry). She received a $\mathrm{PhD}$ from the Hebrew University of Jerusalem in 1960. She then joined her husband to the California Institute of Technology, Pasadena, CA where she worked in the laboratory of Professor R. Dulbeco. She and her family returned in 1962 to Rehovot and was then employed at the Biological Institute in Ness Ziona. In 1965 she joined the Department of Botany at Tel Aviv University where she focused on symbiosis, mainly on lichens. She established her own research group, climbed the ladder of academic promotion to full Professor. She filled several functions at Tel Aviv University: as Dean of Students (1977-1980) and a member of the Rectors Committee. Margalith Galun also held positions outside Tel Aviv University: as vice president of the International Association for Lichenology and served as a member at several executive committees, such as the International Mycological Association. She was a member of the Israel Academy of Science and Humanities Committee for the Israeli collections of fauna and flora. She also established at Tel Aviv University the collection of lichens from Israel and other countries. In 1985 Margalith established the international journal Symbiosis and served as Editor-inChief from 1985-2006.

Margalith served on the editorial boards of several journals (Israel Journal of Botany, Endocytobiosis, Cell Research, Lichen Physiology and Biochemistry). She authored two books: The Lichens of Israel and The Guide to Israeli Lichens (in Hebrew in collaboration with Prof. Garti) and edited the three volumes of The Handbook of Lichenology published by CRC. In addition she published over 90 research articles including reviews, symposia and chapters in scientific books. Until her death she was Professor Emeritus at the Department of Plant Sciences of Tel-Aviv University.
I saw Margalith regularly during her long painful illness. Her mind was clear to the end and she retained her interest in symbiosis to her last days. She had come to the last conferences in Vienna, her home town, and Paris. Accompanied by her devoted son, Eithan, and her devoted aide, Vilma Lim, she planned to come to Cracow even as her strength waned further. She continued as long as she could...

Margalith Galun died on April 16, 2012 after an extended illness. She left her husband, two sons and eight grandchildren.

My tribute to a great scientist, a great friend and a great lady.

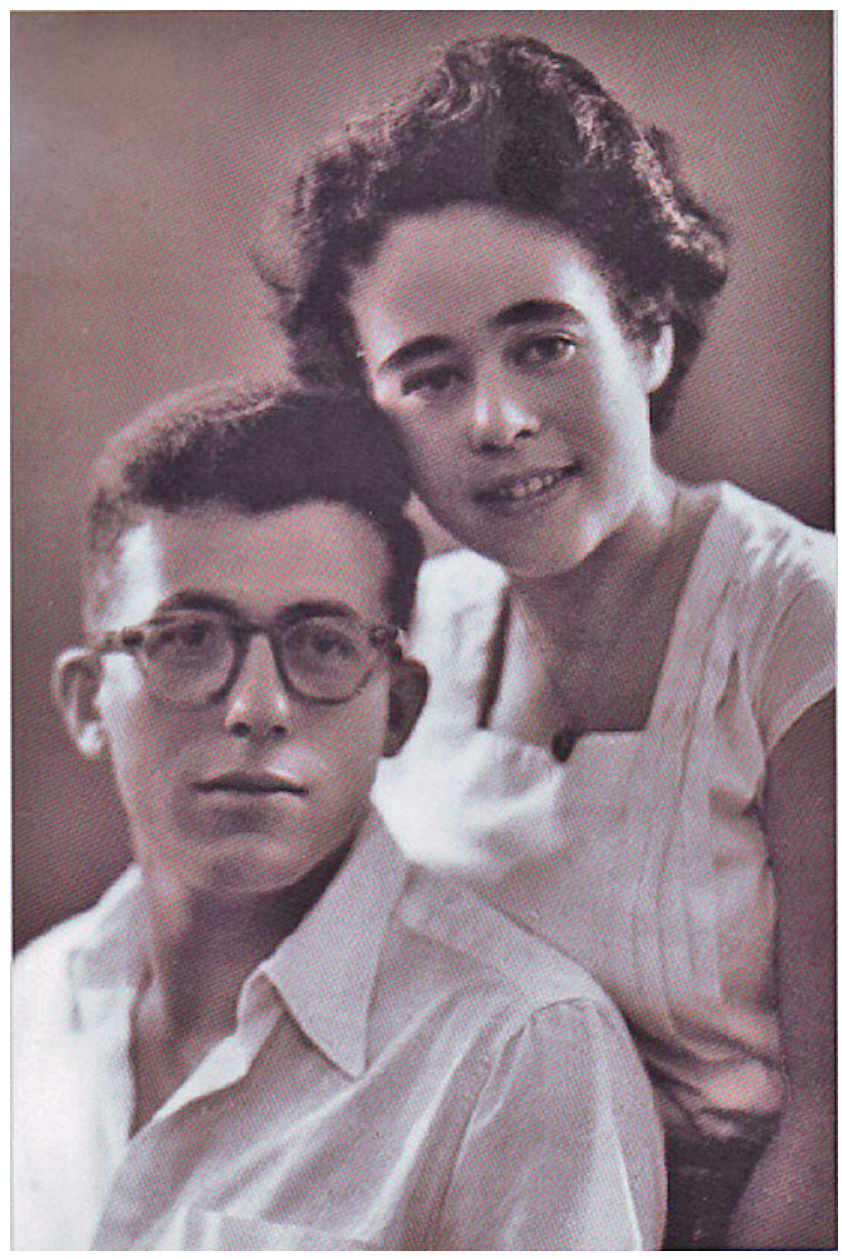

Margalith and Esra Galun 

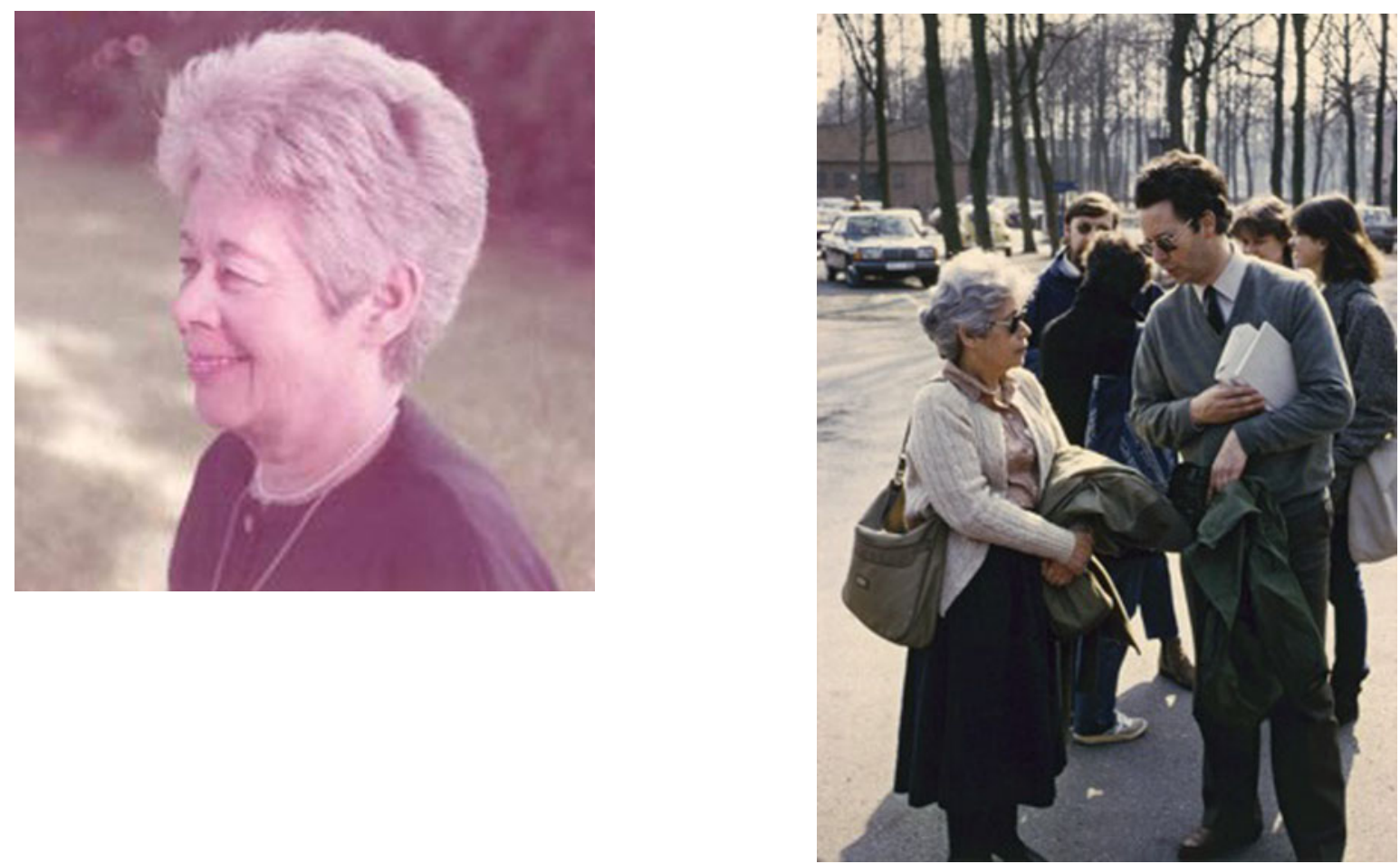

Prof. Margalith Galun with Prof. Mark Seaward.

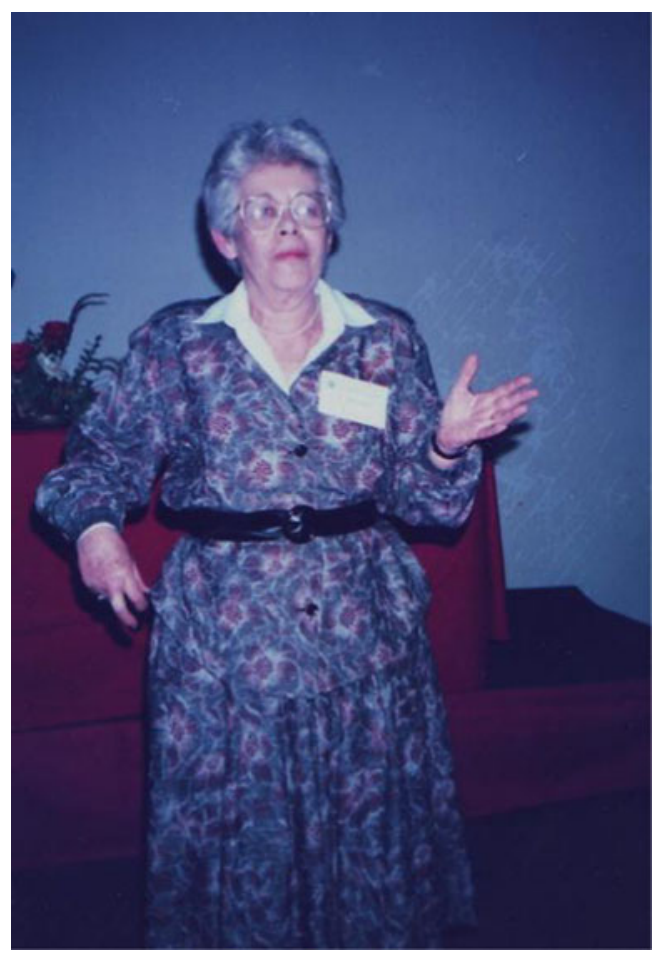

At the Israel-Finland Scientific Research Conference on Symbiotic Systems.

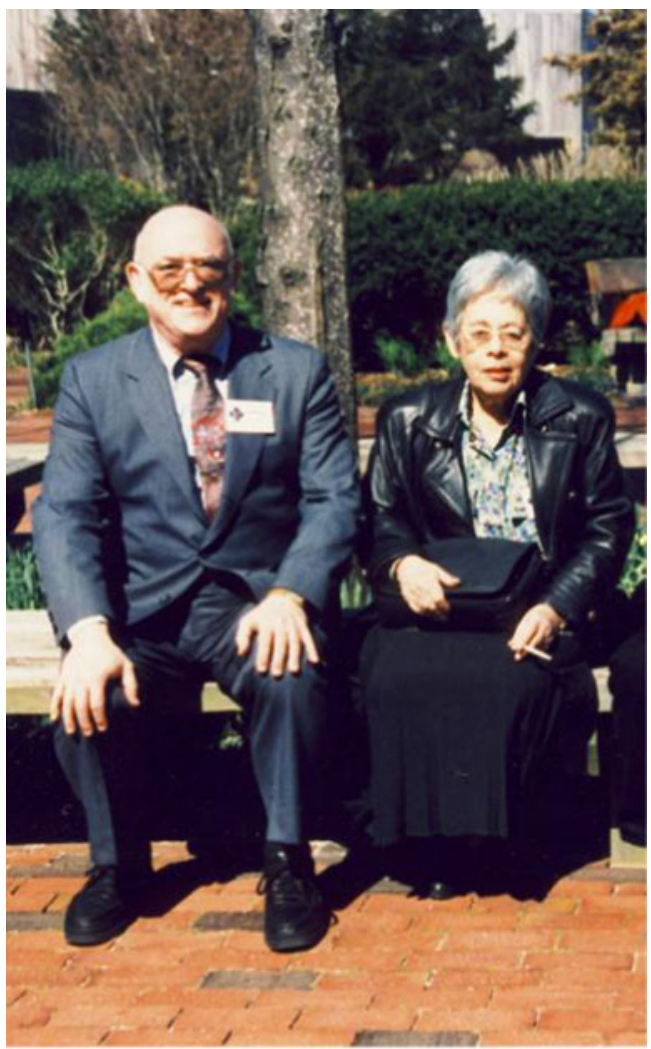

At the 2nd ISS Congress at Woods Hole, MA, USA (1996) where the ISS was formally established: Prof. Margalith Galun with Dr. John Lee, the founding President of the ISS. 


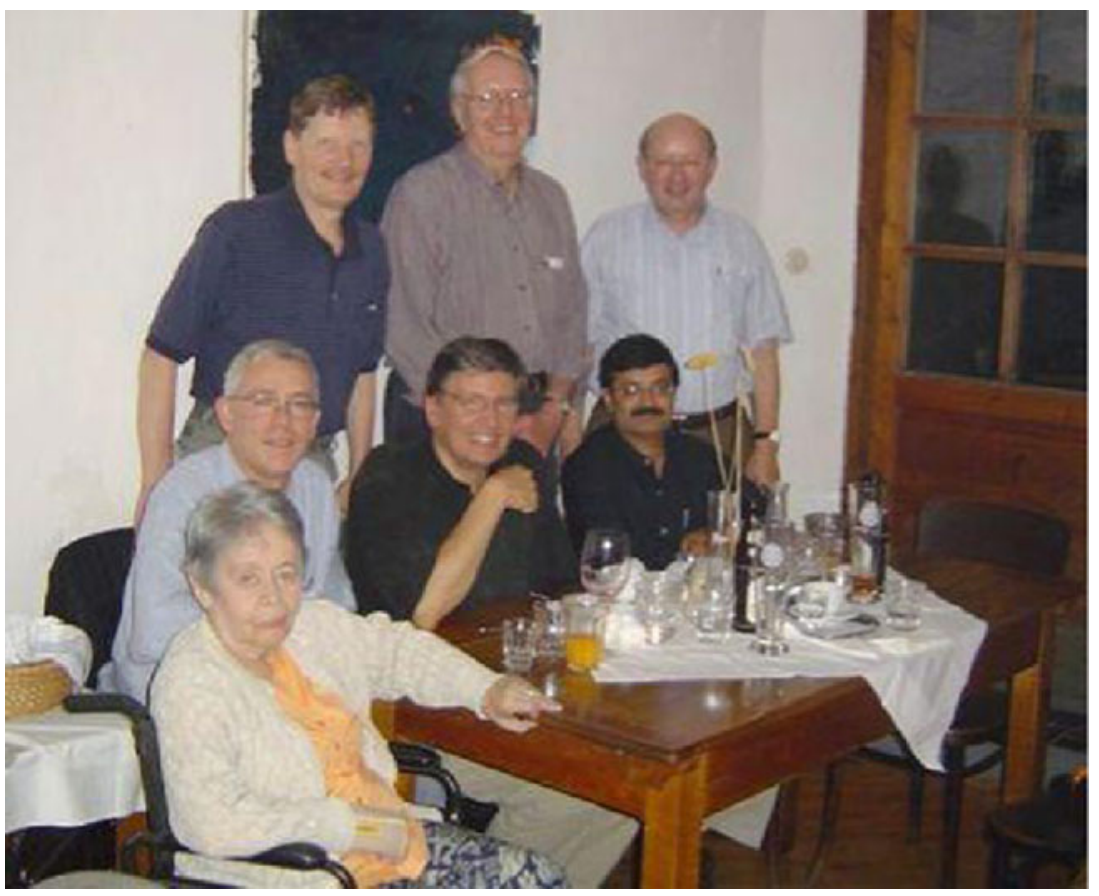

Some members of the Symbiosis Editorial Board at the 5th ISS Congress in Vienna in 2006. Sitting from left to right: The late Prof. Margalith Galun, Margalith's son Dr. Eithan Galun, Prof. Douglas Zook, and the late Dr. Gopi Podila. Standing: Prof. David Richardson, the late Dr. John Streeter, and Dr. Helmut Koenig. 